\title{
Xylopic acid from Xylopia aethiopica (Annonaceae) inhibits morphine tolerance in rats
}

\author{
Priscilla Kolibea Mante ${ }^{1 *}$, Kweku Abakah-Ewusi ${ }^{1}$, Amanda Adoley Mingle ${ }^{1}$, Mustapha Seidu Kpienaan ${ }^{1}$, \\ Samuel Offei-Twum ${ }^{1}$, Nana Kofi Kusi-Boadum ${ }^{1}$, Nana Ofori Adomako ${ }^{2}$, Newman Osafo ${ }^{1}$
}

1 Department of Pharmacology, Faculty of Pharmacy and Pharmaceutical Sciences, Kwame Nkrumah University of Science and Technology, College Of Health Sciences, Kumasi, Ghana

2 Department of Pharmacy Practice, Faculty of Pharmacy and Pharmaceutical Sciences, Kwame Nkrumah University of Science and Technology, College of Health Sciences, Kumasi, Ghana

\begin{abstract}
Traditionally, Xylopia aethiopica is used to manage pain disorders such as neuralgia, colic pain, rheumatism and headache. Using animal models, this study aimed to investigate the ability of Xylopic Acid (XA), a kaurene diterpene obtained from Xylopia aethiopica, to cause tolerance when administered alone or combined with morphine. Development of withdrawal symptoms on discontinuation was also investigated. Tolerance to morphine was induced in rats through an 8-day regimen of chronic administration of morphine $(10 \mathrm{mg} / \mathrm{kg}$; twice daily). Effects of XA alone $(100 \mathrm{mg} / \mathrm{kg})$ or XA $(10-100 \mathrm{mg} / \mathrm{kg})$ on morphine tolerance and withdrawal syndrome precipitated with naloxone hydrochloride $(3 \mathrm{mg} / \mathrm{kg})$ were also assessed. XA's mechanism of action was then explored through drug-receptor binding.

Chronic morphine administration in rats resulted in analgesic tolerance and morphine withdrawal syndrome. Chronic XA administration did not result in tolerance to XA's antinociceptive effect. Development of morphine withdrawal syndrome precipitated by naloxone and morphine tolerance was significantly $(\mathrm{F}(12$, $60)=29.88, p<0.0001)$ inhibited by XA. Xylopic acid inhibited development of diarrhea, jumps and weight loss. Pretreatment with $\alpha$-2-adrenoceptor antagonist, yohimbine, 5HT3 antagonist, ondansetron and muscarinic antagonist, atropine, significantly $(p=0.0042)$ blocked the inhibitory effect of XA on withdrawal jumps. Pretreatment with naloxone produced similar effects on withdrawal jumps as XA alone. Drug-receptor binding assays revealed a lack of significant interaction of XA on alpha-2 adrenoceptors (A, B, C) but exhibited significant DOR- selective antagonism similar to naltrindole. This study reveals that xylopic acid significantly inhibits morphine antinociceptive tolerance and withdrawal in rats. This is the first report of xylopic acid's antagonism on delta opioidergic receptors and potential as an inhibitor of chronic morphine tolerance.
\end{abstract}

\section{Keywords:}

Delta opioid receptor, Naloxone, Pain, Xylopia, Xylopic acid

\section{INTRODUCTION}

Opioids have for many years played an instrumental role in the relief of moderate to severe pain ${ }^{1-2}$. Opioids act through interaction with the superfamily of G-protein-coupled opioid receptors: $m \mu$, kappa, and delta. All subtypes of opioid receptors modulate pain perception, excluding the kappa 2 receptor. All three receptor subtypes inhibit adenylyl cyclase, suppress calcium con- ductance, activate potassium conductance and inhibit neurotransmitter release ${ }^{1-2}$. The benefits of the antinociceptive effect of opioids have unfortunately been limited due to increased tolerance and dependence upon chronic $u^{3} e^{3}$. For patients with pain which may or may not be associated with malignancy and in palliative care, the likelihood of developing analgesic tolerance or opioid dependence due to pain therapy is very high ${ }^{4}$. Opioid tolerance usually results in a decreased responsiveness

*Corresponding author:

*Priscilla Kolibea Mante Email: pkmante.pharm@knust.edu.gh. 
to an opioid agonist such as morphine; a dose escalation is usually required in such an instance ${ }^{5}$. Dependence on opioid drugs results in compulsive use of these drugs. Moreover an attempt to abruptly cease consumption commonly triggers withdrawal signs ${ }^{6}$. These signs may be mitigated by administration of drugs like clonidine and methadone ${ }^{7}$. Multilayered mechanisms have been associated with opioid tolerance and dependence such as the generation of free radicals, down-regulation of opioid receptors and activation of the N-methyl-Daspartate (NMDA) glutamatergic receptor ${ }^{8-9}$.

Xylopic acid, a kaurene diterpene from Xylopia aethiopica (Annonaceae), possesses many therapeutic benefits. Among these is its antinociceptive effect ${ }^{10-11}$. Woode et al. previously reported xylopic acid's antinociceptive mechanism ${ }^{11}$. Xylopic acid possibly acts by opioidergic, NO-cGMP, serotoninergic, cholinergic, adrenergic, and adenosinergic mechanisms. Opioidergic activity of XA suggests a possibility of development of tolerance, dependence or withdrawal symptoms on chronic use. Given, the common use of Xylopia aethiopica (X. aethiopica) in the Ghanaian traditional society, our study sought to investigate xylopic acid for the possibility of tolerance on chronic use as well as its effect on tolerance to morphine and withdrawal syndrome in animal models.

\section{MATERIALS AND METHODS}

\subsection{Drugs}

Atropine and ondansetron (GlaxoSmithKline, Middlesex, UK), Morphine and Naloxone HCL Injection (Sandoz Canada Incorporated, Boucherville, Canada), Yohimbine (Walter Ritter GmbH, Hamburg, Germany).

\subsection{Experimental animals}

Rats (200-250 g Male Sprague-Dawley) obtained from the Noguchi Memorial Institute for Medical Research, Accra, Ghana, were kept under laboratory conditions in steel cages with free access to tap water and food. Animals were given seven (7) days to adapt to the laboratory environment before experiments began. Rats were put in experimental groups $(n=8)$ randomly. Faculty Animal Ethics Committee, Kwame Nkrumah University of Science and Technology, granted ethical approval for the study.

\subsection{Xylopic acid extraction}

The extraction of xylopic acid from Xylopia aethiopica was done as reported by Boampong $\mathrm{J}$ and colleagues ${ }^{12}$. Fresh unripe fruits of $X$. aethiopica were obtained from the Botanic Gardens of KNUST $\left(06^{\circ}\right.$ $41^{\prime} 6.38^{\prime \prime} \mathrm{N}$; $01^{\circ} 33^{\prime} 44.34^{\prime \prime}$ W). X. aethiopica has been stored at the KNUST herbarium (Voucher number FP/09/77). The fruits were shade-dried and pulverized. Two (2) $\mathrm{kg}$ of powdered sample was soaked for 3 days in $5 \mathrm{~L}$ of petroleum ether $\left(40-60^{\circ} \mathrm{C}\right)$. The petroleum ether was drained and a rotary evaporator was used to obtain a concentrate of the sample at $50^{\circ} \mathrm{C}$. Ethyl acetate was then added to the concentrate to crystalize xylopic acid out of the mixture. The xylopic acid crystals were allowed to stand for three days after which they were flushed repeatedly with petroleum ether $\left(40-60^{\circ} \mathrm{C}\right)$ to rid the crystals of all unwanted materials. Purification of xylopic acid fraction using 96\% v/v ethanol to obtain $95 \%$ purity was done. Purity was determined using HPLC.

\subsection{Antinociceptive test}

Antinociceptive testing was done using the hot water immersion tail-withdrawal assay as performed by Steimiller CL and colleague ${ }^{13}$. The distal half of the rat's tail was dipped into a water bath containing hot water (Temperature: $50 \pm 1.0^{\circ} \mathrm{C}$ ) and tail withdrawal latency measured. Tissue damage was prevented with a cut-off time of ten seconds. In measuring antinociception, an increase in tail withdrawal latency was used. Animals that failed to withdraw their tails were awarded the cutoff latency and the experiment immediately ended. Antinociception was calculated as follows:

Eq. (1): \%Antinociception (\%MPE) $=[(\mathrm{Tb}-\mathrm{Ta}) /$ $(\mathrm{T} 0-\mathrm{Ta}) \times 100]$, where $\mathrm{Ta}=$ pre-drug withdrawal latency; $\mathrm{Tb}=$ post-drug withdrawal latency; $\mathrm{T} 0=$ cut-off latency.

\subsection{Morphine tolerance induction}

Twice daily dosing (7:00 a.m. and 6:00 p.m.) of $10 \mathrm{mg} / \mathrm{kg}$; i.p. morphine was done for eight (8) days. On days 1, 3, 6 and 8, the tail-withdrawal assay was used to measure antinociception $30 \mathrm{~min}$ prior to, and after morphine administration. Xylopic Acid was administered either alone $(100 \mathrm{mg} / \mathrm{kg}$; p.o.) or together (XA, 10$100 \mathrm{mg} / \mathrm{kg}$; p.o.) with morphine (10 mg/kg; i.p.). On the days of antinociceptive testing, xylopic acid was given after morphine administration and antinociception testing was conducted (Figure 1).

\subsection{Induction of morphine withdrawal syndrome}

Intraperitoneal injections of morphine were administered twice daily for 7 days as follows: 2.5 $\mathrm{mg} / \mathrm{kg}$ on days 1 and 2 , and doubled every subsequent day. Forty (40) mg/kg was given on day 6 and $50 \mathrm{mg} / \mathrm{kg}$ on day 7. Xylopic acid (10-100 mg/kg) was dosed 20 min before morphine to investigate possible effects on the occurrence of morphine withdrawal syndrome. On day $7,3 \mathrm{mg} / \mathrm{kg}$ of intraperitoneal naloxone hydrochloride was administered $5 \mathrm{~h}$ following the last administration of morphine. Subsequent to administration of naloxone, 


\begin{tabular}{|c|c|c|c|c|c|c|c|c|}
\hline \multirow[b]{2}{*}{ Groups } & \multicolumn{8}{|c|}{ Days } \\
\hline & 1 & 2 & 3 & 4 & 5 & 6 & 7 & 8 \\
\hline Vehicle & $\begin{array}{c}\text { Saline twice } \\
\text { daily }\end{array}$ & $\begin{array}{l}\text { Saline twice } \\
\text { daily }\end{array}$ & $\begin{array}{c}\text { Saline twice } \\
\text { daily }\end{array}$ & $\begin{array}{l}\text { Saline twice } \\
\text { daily }\end{array}$ & $\begin{array}{c}\text { Saline twice } \\
\text { daily }\end{array}$ & $\begin{array}{c}\text { Saline twice } \\
\text { daily }\end{array}$ & $\begin{array}{l}\text { Saline twice } \\
\text { daily }\end{array}$ & $\begin{array}{c}\text { Saline twice } \\
\text { daily }\end{array}$ \\
\hline $\begin{array}{l}\text { Morphine- } \\
\text { only }\end{array}$ & $\begin{array}{l}\text { Morphine } \\
\text { twice daily }\end{array}$ & $\begin{array}{l}\text { Morphine } \\
\text { twice daily }\end{array}$ & $\begin{array}{l}\text { Morphine } \\
\text { twice daily }\end{array}$ & $\begin{array}{l}\text { Morphine } \\
\text { twice daily }\end{array}$ & $\begin{array}{l}\text { Morphine } \\
\text { twice daily }\end{array}$ & $\begin{array}{l}\text { Morphine } \\
\text { twice daily }\end{array}$ & $\begin{array}{l}\text { Morphine } \\
\text { twice daily }\end{array}$ & $\begin{array}{l}\text { Morphine } \\
\text { twice daily }\end{array}$ \\
\hline XA-only & XA twice daily & XA twice daily & XA twice daily & XA twice daily & XA twice daily & XA twice daily & XA twice daily & XA twice daily \\
\hline XA-Morphine & $\begin{array}{c}\text { XA + } \\
\text { Morphine } \\
\text { twice daily }\end{array}$ & $\begin{array}{c}\text { XA+ } \\
\text { Morphine } \\
\text { twice daily }\end{array}$ & $\begin{array}{c}\text { XA + } \\
\text { Morphine } \\
\text { twice daily }\end{array}$ & $\begin{array}{c}\text { XA + } \\
\text { Morphine } \\
\text { twice daily }\end{array}$ & $\begin{array}{c}\text { XA + } \\
\text { Morphine } \\
\text { twice daily }\end{array}$ & $\begin{array}{c}\text { XA + } \\
\text { Morphine } \\
\text { twice daily }\end{array}$ & $\begin{array}{c}\text { XA + } \\
\text { Morphine } \\
\text { twice daily }\end{array}$ & $\begin{array}{c}\text { XA+ } \\
\text { Morphine } \\
\text { twice daily }\end{array}$ \\
\hline & $\begin{array}{c}\text { Tail } \\
\text { withdrawal } \\
\text { test }\end{array}$ & & $\begin{array}{c}\text { Tail } \\
\text { withdrawal } \\
\text { test }\end{array}$ & & & $\begin{array}{c}\text { Tail } \\
\text { withdrawal } \\
\text { test }\end{array}$ & & $\begin{array}{c}\text { Tail } \\
\text { withdrawal } \\
\text { test }\end{array}$ \\
\hline
\end{tabular}

Figure 1. Scheme for morphine tolerance induction.

\begin{tabular}{|c|c|c|c|c|c|c|c|}
\hline & \multicolumn{7}{|c|}{ Days } \\
\hline Groups & 1 & 2 & 3 & 4 & 5 & 6 & 7 \\
\hline Vehicle & $\begin{array}{l}\text { Saline twice } \\
\text { daily }\end{array}$ & $\begin{array}{l}\text { Saline twice } \\
\text { daily }\end{array}$ & $\begin{array}{l}\text { Saline twice } \\
\text { daily }\end{array}$ & $\begin{array}{c}\text { Saline twice } \\
\text { daily }\end{array}$ & $\begin{array}{l}\text { Saline twice } \\
\text { daily }\end{array}$ & $\begin{array}{l}\text { Saline twice } \\
\text { daily }\end{array}$ & $\begin{array}{l}\text { Saline twice } \\
\text { daily }\end{array}$ \\
\hline $\begin{array}{l}\text { Morphine- } \\
\text { only }\end{array}$ & $\begin{array}{l}\text { Morphine } \\
\text { twice daily }\end{array}$ & $\begin{array}{l}\text { Morphine } \\
\text { twice daily }\end{array}$ & $\begin{array}{l}\text { Morphine } \\
\text { twice daily }\end{array}$ & $\begin{array}{l}\text { Morphine } \\
\text { twice daily }\end{array}$ & $\begin{array}{l}\text { Morphine } \\
\text { twice daily }\end{array}$ & $\begin{array}{l}\text { Morphine } \\
\text { twice daily }\end{array}$ & $\begin{array}{l}\text { Morphine } \\
\text { twice daily }\end{array}$ \\
\hline XA-only & XA twice daily & XA twice daily & XA twice daily & XA twice daily & XA twice daily & XA twice daily & XA twice daily \\
\hline \multirow[t]{2}{*}{ XA-Morphine } & $\begin{array}{c}\text { XA + } \\
\text { Morphine } \\
\text { twice daily }\end{array}$ & $\begin{array}{c}\text { XA + } \\
\text { Morphine } \\
\text { twice daily }\end{array}$ & $\begin{array}{c}\text { XA+ } \\
\text { Morphine } \\
\text { twice daily }\end{array}$ & $\begin{array}{c}\text { XA + } \\
\text { Morphine } \\
\text { twice daily }\end{array}$ & $\begin{array}{c}\mathrm{XA}+ \\
\text { Morphine } \\
\text { twice daily }\end{array}$ & $\begin{array}{c}\text { XA + } \\
\text { Morphine } \\
\text { twice daily }\end{array}$ & $\begin{array}{c}\text { XA + } \\
\text { Morphine } \\
\text { twice daily }\end{array}$ \\
\hline & & & & & & & $\begin{array}{c}\text { Naloxone } 5 \mathrm{~h} \\
\text { after last } \\
\text { treatment }\end{array}$ \\
\hline
\end{tabular}

Figure 2. Scheme for induction of morphine withdrawal syndrome.

animals were individually put into a transparent observation chamber and observed for occurrence of withdrawal signs (Figure 2). Both quantitative (increased frequency of jumps and abdominal contractions) and qualitative (diarrhea, weight loss) signs were noted according to work by de Corde $\mathrm{A}$ and colleagues $^{14}$. Activity of XA $(30 \mathrm{mg} / \mathrm{kg})$ was blocked with selected antagonists yohimbine $(2.5 \mathrm{mg} / \mathrm{kg}$; p.o.), atropine (5 $\mathrm{mg} / \mathrm{kg}$; p.o.), Ondansetron ( $0.5 \mathrm{mg} / \mathrm{kg}$; p.o.), naloxone ( $2 \mathrm{mg} / \mathrm{kg}$; i.p.) towards determination of its mechanism of action. XA ( $30 \mathrm{mg} / \mathrm{kg})$ was selected as it was the median effective dose for xylopic acid.

\subsection{Drug receptor binding}

For primary binding assays, compounds were sampled at a single concentration $(10 \mu \mathrm{M})$ as well as quadruplicates $(0.16,0.32,0.63,1.25,2.5,5.0$ and 10.0 $\mathrm{nM})$. Compounds which exhibited a minimum of $50 \%$ inhibition at $10 \mu \mathrm{M}$ were then tagged for secondary radioligand binding assays to determine equilibrium binding affinity at specific targets. In secondary binding assays, compounds were tested at 11 concentrations $(0.1,0.3,1,3,10,30,100,300 \mathrm{nM}, 1,3,10 \mu \mathrm{M})$ and in triplicates.

Ki determinations and receptor binding profiles were generously provided by the National Institute of Mental Health's Psychoactive Drug Screening Program, Contract \#HHSN-271-2018-00023-C (NIMH PDSP). The NIMH PDSP is directed by Bryan L. Roth at the University of North Carolina at Chapel Hill and Project Officer Jamie Driscoll at NIMH, Bethesda MD, USA. For experimental details please refer to the PDSP web site https://pdsp.unc.edu/ims/investigator/web/.

\subsection{Data analysis}

Data were stated as mean \pm S.E.M and significant differences between means calculated by one-way analysis of variance (ANOVA) and two-way ANOVA followed by Tukey post hoc test. In all instances, $p<0.05$ was considered significant. Statistical analyses were carried out with GraphPad Prism ${ }^{\circledR}$ Version 8.0 (GraphPad Software, San Diego, CA, USA). 


\section{RESULTS}

\subsection{Xylopic acid extraction}

Isolated xylopic acid purity was determined using HPLC. The resultant single peak for xylopic acid indicated a single compound was present (Figure 3).

\subsection{Morphine tolerance induction}

As shown in Figure 4, there was a decrease in antinociceptive effect after chronic administration of morphine. This was taken as a measure of tolerance onset. Concomitant administration of morphine with XA (30 and $100 \mathrm{mg} / \mathrm{kg})$ significantly $(\mathrm{F}(12,60)=29.88$, $p<0.0001)$ inhibited morphine tolerance. Treatment with XA only showed antinociceptive effect without tolerance.

\subsection{Induction of morphine withdrawal syndrome}

Administration of naloxone induced diarrhea in morphine only-treated rats. Vehicle only-treated rats, in contrast, did not exhibit diarrhea. Concurrent morphine administration with $100 \mathrm{mg} / \mathrm{kg}$ XA decreased the number of rats with diarrhea significantly $(p<0.01)$.

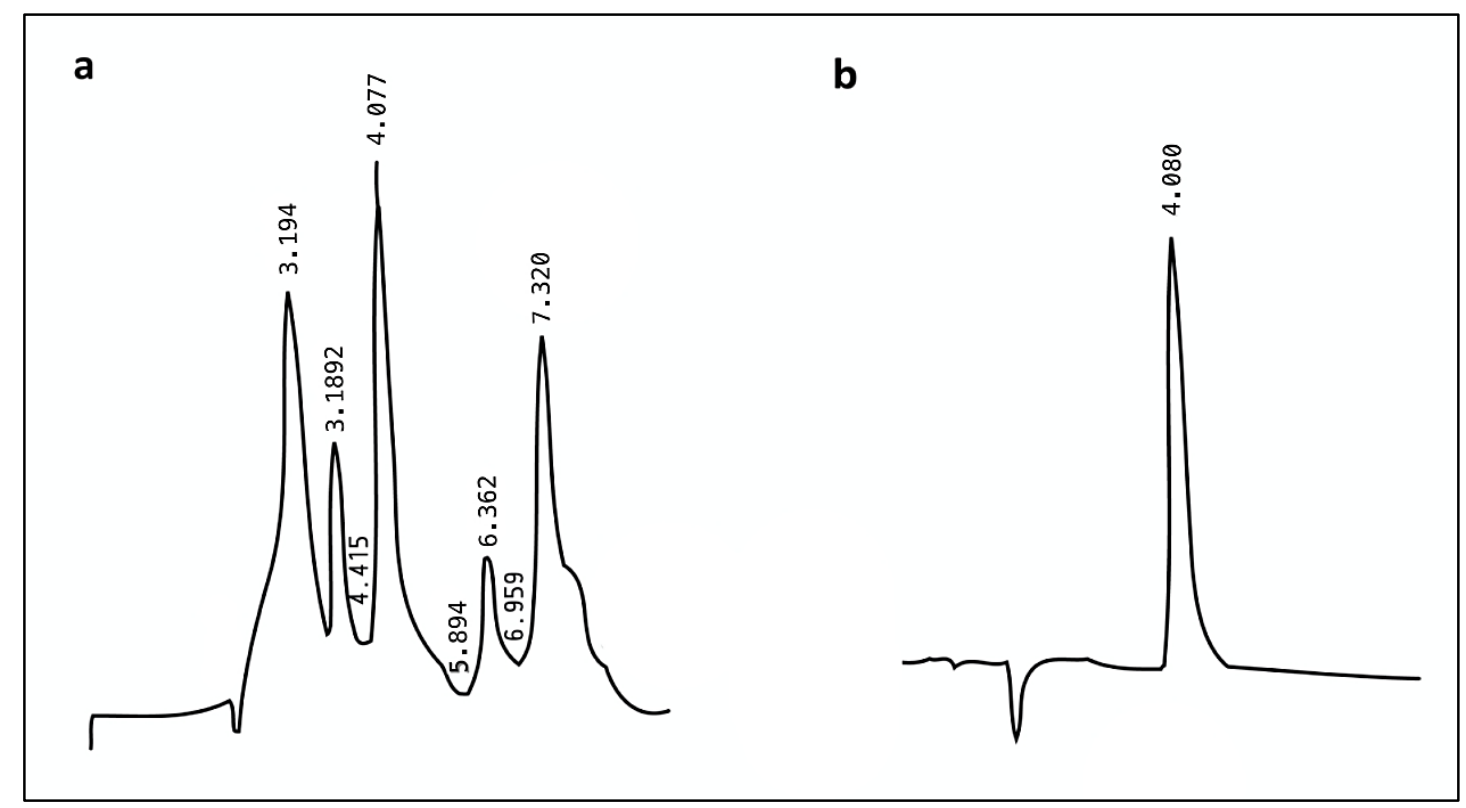

Figure 3. HPLC chromatogram of a) Xylopia crude extract b) xylopic acid.

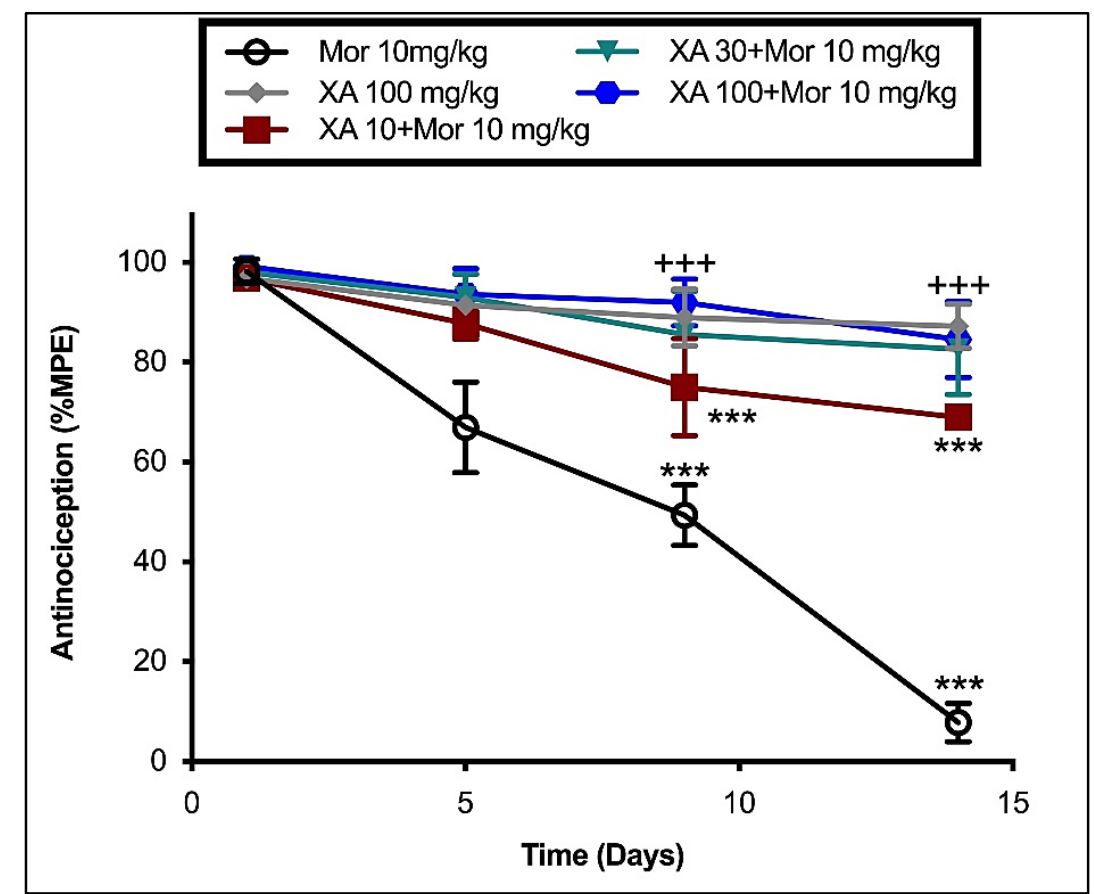

Figure 4. Xylopic Acid (XA; $10-100 \mathrm{mg} / \mathrm{kg}$ ) effect on development of morphine tolerance in rats $(\mathrm{n}=8)$. Points represent mean \pm S.E.M. +++ $p<0.001$ as compared with morphine-injected rats on the same day, $*_{* *}^{*}<0.001$ indicates significant difference vs $\%$ MPE obtained on the first day. 
Table 1. Withdrawal signs exhibited by animals after naloxone hydrochloride administration in morphine-dependent rats.

\begin{tabular}{lcc}
\hline Treatment Groups & Withdrawal Signs (number of animals with sign/number observed) \\
\cline { 2 - 3 } & Diarrhea & Weight Loss \\
\hline Veh & $0 / 8$ & $0 / 8$ \\
Mor & $8 / 8^{* * *}$ & $8 / 8^{* * *}$ \\
XA & $0 / 8+++$ & $2 / 8+$ \\
Mor+XA10 & $6 / 8^{*}$ & $7 / 8^{* * *}$ \\
Mor+XA30 & $4 / 8^{*+}$ & $3 / 8+$ \\
Mor+XA100 & $1 / 8++$ & $2 / 8+$ \\
\hline
\end{tabular}

$* p<0.05, * * p<0.01, * * * p<0.001$ significantly different compared with Veh group.

$+p<0.05,++p<0.01,+++p<0.001$ in comparison to morphine-only group, one-way ANOVA followed by Tukey Post Hoc test.

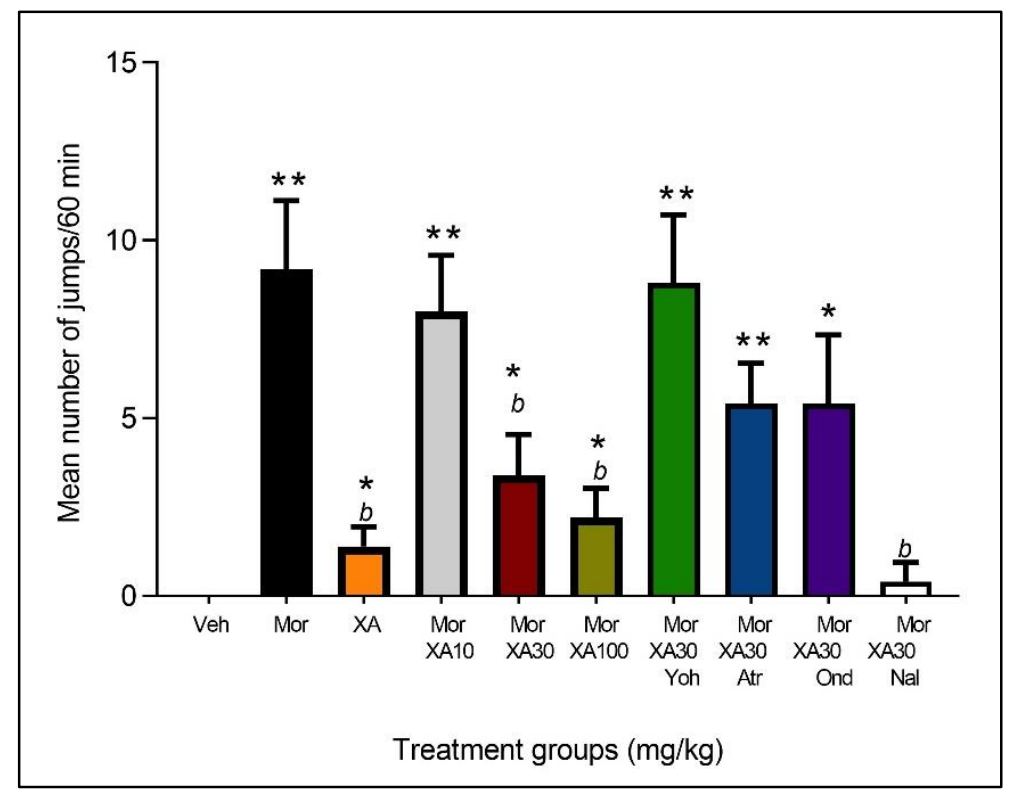

Figure 5. Effect of XA (10-100 mg/kg), naloxone ( $2 \mathrm{mg} / \mathrm{kg})$, yohimbine $(2.5 \mathrm{mg} / \mathrm{kg})$, atropine $(5 \mathrm{mg} / \mathrm{kg})$, Ondansetron $(0.5 \mathrm{mg} / \mathrm{kg}) \mathrm{on} \mathrm{naloxone-}$ induced jumps in rats $(\mathrm{n}=8)$. Results represent mean \pm S.E.M. ${ }^{*} p<0.05, * * p<0.01$ vs. control rats. $\mathrm{b} p<0.05$, in comparison with morphine-treated animals.

Animals that received morphine $+30 \mathrm{mg} / \mathrm{kg}$ XA exhibited a reduction of diarrheal signs by half. There was no significant reduction of diarrhea signs in Morphine $+10 \mathrm{mg} / \mathrm{kg}$ XA-treated groups. Results also indicated that naloxone administration led to significant $(p<0.001)$ loss of weight in all rats treated with morphine only compared to the vehicle-treated group. In XA only-treated rats, naloxone administration produced weight loss in two animals. XA at 30 and $100 \mathrm{mg} / \mathrm{kg}$ administered concurrently with morphine reduced weight loss precipitated by naloxone, significantly $(p<0.05)$. Concomitant administration of XA $(10 \mathrm{mg} / \mathrm{kg})$ with morphine produced no significant effect on weight loss (Table 1).

\subsection{Naloxone-induced jumping in morphine- dependent rats}

XA (10 mg/kg) could not significantly reduce the mean number of naloxone-induced jumps. At 30 and $100 \mathrm{mg} / \mathrm{kg}$ however, a significant $(\mathrm{F}(2.564,10.26)=32.63$, $P=0.0251)$ reduction in the frequency of jumps was observed when XA was co-administered with morphine
(Figure 5). Pretreatment with yohimbine, atropine and ondansetron resulted in significant reversal of withdrawal jumps in rats. Pretreatment with naloxone resulted in a similar effect on withdrawal jumps as XA alone.

\subsection{Naloxone-induced abdominal contractions in morphine-dependent rats}

Frequency of abdominal contractions after administration of naloxone increased significantly $(\mathrm{F}(1.771,7.082)=25.37, P=0.0013)$ in morphine onlytreated groups. Concurrent administration of morphine and XA did not inhibit abdominal contraction induced by naloxone (Figure 6). XA-only administration insignificantly affected naloxone-induced abdominal contracts.

\subsection{Radioligand Binding Assay}

Primary binding assays (Table 2) showed stimulatory effects of xylopic acid on Kappa and $M \mu$ receptors. It however displayed antagonism on Delta and Sigma 2 receptors. Significant (greater than 50\% inhibition) among these interactions was the Delta 
Table 2. Mean percentage inhibition (in vitro) of xylopic acid on various opioidergic receptors.

\begin{tabular}{lc}
\hline Receptor & Mean \% Inhibition $(* \boldsymbol{p}<\mathbf{0 . 0 5})$ \\
\hline DOR & $66.08 \pm 4.3^{*}$ \\
KOR & $-1.8 \pm-7.792$ \\
MOR & $-19.39 \pm-4.6$ \\
Sigma 2 & $49.02 \pm 1.0$ \\
Alpha 2A & $-8.518 \pm 13.00$ \\
Alpha 2B & $19.58 \pm 9.323$ \\
Alpha 2C & $-3.023 \pm 0.5405$ \\
M4 & $3.125 \pm 1.429$ \\
M5 & $8.330 \pm 2.428$ \\
5HT3 & $4.293 \pm 5.906$ \\
\hline
\end{tabular}

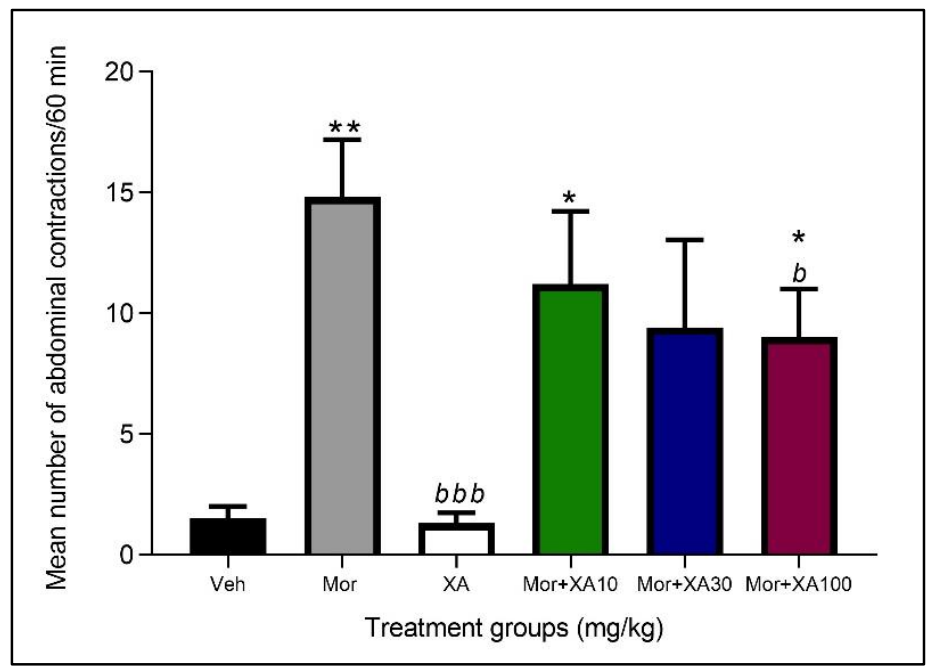

Figure 6. Effect of XA $(10-100 \mathrm{mg} / \mathrm{kg} ; \mathrm{n}=8)$ on abdominal contractions induced by naloxone. Results represent mean \pm S.E.M. * $p<0.05$, ** $p<0.01$ vs. vehicle-treated rats. $\mathrm{b} p<0.05$, bbb $p<0.001$, in comparison with morphine-treated animals.

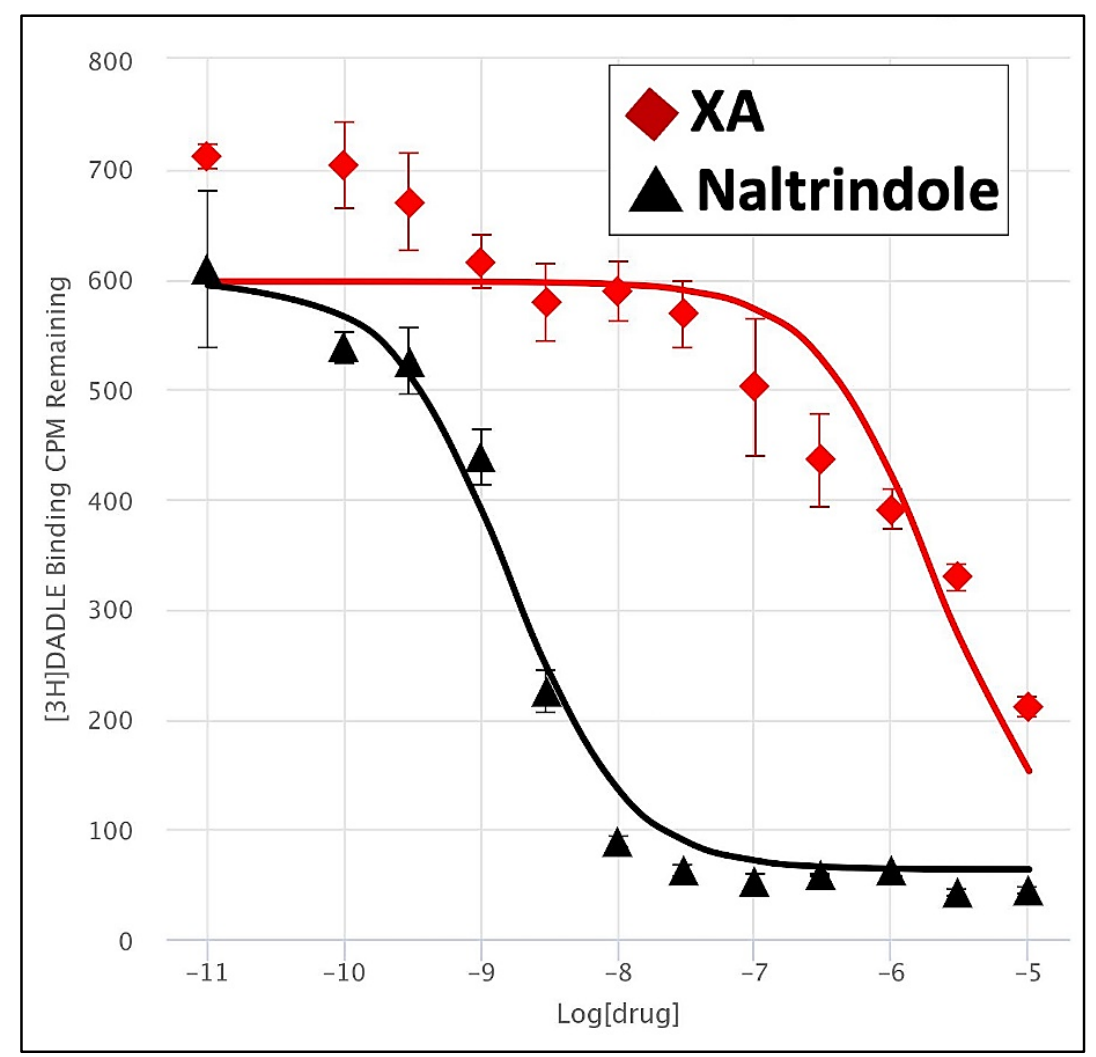

Figure 7. Secondary binding curve of $[3 \mathrm{H}] \mathrm{DADLE}$ on human delta opioid receptor in the presence of Naltrindole and xylopic acid. Results represent mean \pm S.E.M from three experiments. 
Table 3. Secondary binding assay of xylopic acid on delta opioidergic receptors.

\begin{tabular}{lrr}
\hline Drug & Log Ki & Ki (nM) \\
\hline Xylopic Acid & -5.97 & 1073.49 \\
Naltrindole & -9.08 & 0.84 \\
\hline
\end{tabular}

receptor antagonism $(66.08 \pm 4.3 \%)$. Further secondary binding assay indicated inhibitory action of xylopic acid on delta opioid receptor using naltrindole as standard (Figure 7). Ki value of xylopic acid was $1073.49 \mathrm{nM}$ compared to naltrindole, $0.84 \mathrm{nM}$ (Table 3). Interaction of XA with muscarinic, alpha-adrenergic and serotoninergic receptors were not significant.

\section{DISCUSSION}

Our results show that XA possesses a significant anti-tolerance effect against morphine-induced antinociception in rats and is not liable to induce tolerance on chronic administration. XA, additionally, alleviated some signs of withdrawal in rats with morphine-dependence. Woode et al., previously demonstrated that tolerance to analgesic or cross-tolerance when combined with morphine does not occur with chronic administration of XA.

The two major theories hypothesized for opioid tolerance involve changes in opioid receptors and adaptations at various levels in the nervous system as well as in the periphery. Nonetheless, these significant changes are initiated by $m \mu$ receptor activation.

Prolonged opioid activation of $m \mu$ receptors is believed to result in changes that lead either to receptor desensitization or receptor down-regulation ${ }^{15}$. However, other mechanisms have been proposed, including actions mediated by the delta opioid receptor. M $\mu$-opioid receptors (MOR)-delta opioid receptors (DOR) heterodimerization has previously been found to be an important mechanism in the development of opioid tolerance ${ }^{16}$. In the primary binding assay, XA exhibited some activity on $m \mu$, delta, kappa and Sigma 2 receptors; delta receptor binding however was most significant. The secondary binding assay on delta displayed a similarity between the slopes of the standard, naltrindole, and XA. In a study conducted by Reiss D and colleagues ${ }^{17}$, the involvement of the opioid receptor delta in opioid tolerance was discussed. Receptor internalization is a key feature of the activation of the delta opioid receptor. Contrasting the $m \mu$ opioidergic receptor which can undergo recycling to the surface of the cell upon internalization ${ }^{18}$, opioid receptors (delta) are degraded by lysosomes. This receptor inactivation contributes to the onset of opioid tolerance ${ }^{19}$. Investigations in relation to the mechanism of opioid tolerance and dependence have shown an involvement of the delta and $m \mu$ receptors. Abdelhamid et al. ${ }^{20}$, discovered that naltrindole was able to prevent morphine tolerance in male swisswebster mice. This establishes that delta receptor antagonism is able to attenuate opioid tolerance and could therefore be XA's mechanism of morphine tolerance attenuation.

Release of several neurotransmitters and subsequent activation of the receptor accompany the opioid withdrawal syndrome. Alterations of specific physiological functions are responsible for the individual signs of withdrawal observed ${ }^{21}$. The withdrawal signs investigated were diarrhea, weight loss, mean number of jumps per 60 minutes, and mean number of abdominal contractions ${ }^{14,22-24}$. Research provides evidence suggesting an association of the cholinergic system with biological activity of opiates ${ }^{25}$. Rada and colleagues ${ }^{26}$ induced morphine withdrawal in rats and discovered that there was a decline in dopamine and a surge in acetylcholine concentration in the nucleus accumbens. Acetylcholine elevation is responsible for the increase in peristaltic movement, resulting in the diarrhea and abdominal contraction associated with withdrawal syndrome ${ }^{27}$. Many studies have also proven that withdrawal signs are due to the locus coeruleus ${ }^{28,29}$. This involves an elevation in the levels of noradrenaline ${ }^{30}$. The ability of clonidine, an $\alpha-2$ receptor agonist, to alleviate withdrawal signs confirms the involvement of noradrenaline in the onset of opioid withdrawal ${ }^{21,26,30}$. Motricity, in various studies, has been identified as a sign of withdrawal. In a study by Mavrikaki $\mathrm{M}$ and colleagues ${ }^{21}$, clothaipine's ability to reduce the frequency of jumps was associated with the inhibition of dopamine receptors produced by this drug. Bläsig J et al. ${ }^{31}$ also conducted a study that revealed dopamine played a stimulatory role in the induction of jumping behavior in rats with naloxone-induced withdrawal.

In this study, the morphine group elicited withdrawal signs (diarrhea, weight loss, increased abdominal contractions, elevated frequency of jumps) similar to work done by Bläsig $\mathrm{J}$ and colleagues ${ }^{32}$. Co-administration of morphine and high dose XA attenuated all the signs of withdrawal except abdominal contractions. In a prior study, pretreatment of rats with the $\alpha-2$ adrenoceptor antagonist, yohimbine reversed the antinociception produced by xylopic acid administration ${ }^{33}$. This implies that xylopic acid interacts with the $\alpha-2$ adrenoceptor or adrenergic pathway and this may be the mechanism by which, like clonidine ${ }^{30}$, XA alleviates morphine withdrawal. Yohimbine produced similar actions in this study. However, drug receptor binding failed to establish significant interaction of xylopic acid with the $\alpha-2$ adrenoceptor. It may therefore be a possibility that xylopic acid may be acting downstream in the 
$\alpha-2$ adrenoceptor cascade.

\section{CONCLUSIONS}

In conclusion, xylopic acid administration in rat models has been shown to possess significant inhibitory action on withdrawal syndrome induced by naloxone and against tolerance to antinociceptive effects of morphine. The anti-tolerance ability of XA may be associated with delta opioid receptor blockade. XA's ability to alleviate withdrawal may be mediated by interaction with the adrenergic system. Further work may be required to confirm this effect.

\section{Conflict of interest}

The authors declare no conflicts of interests.

\section{Funding}

None to declare.

\section{Ethics approval}

This study was approved by Faculty Animal Ethics Committee, Kwame Nkrumah University of Science and Technology No. FP/A.11/TJ.

\section{Article info:}

Received July 7, 2021

Received in revised form October 20, 2021

Accepted October 20, 2021

\section{REFERENCES}

1. Ballantyne JC, Shin NS. Efficacy of opioids for chronic pain: a review of the evidence. Clin J Pain. 2008;24(6):469-78.

2. Guo KK, Deng CQ, Lu GJ, Zhao GL. Comparison of analgesic effect of oxycodone and morphine on patients with moderate and advanced cancer pain: a meta-analysis. BMC Anesthesiol. 2018; 18(1):1-9.

3. Smith MT, Mun CJ, Remeniuk B, Finan PH, Campbell CM, Buenaver LF, et al. Experimental sleep disruption attenuates morphine analgesia: findings from a randomized trial and implications for the opioid abuse epidemic. Sci Rep. 2020;10(1): $1-2$.

4. Childers JW, King LA, Arnold RM. Chronic pain and risk factors for opioid misuse in a palliative care clinic. Am J Hosp Palliat Care. 2015;32(6):654-59.

5. Kaplovitch E, Gomes T, Camacho X, Dhalla IA, Mamdani MM, Juurlink DN. Sex differences in dose escalation and overdose death during chronic opioid therapy: a population-based cohort study. PloS one. 2015;10(8):e0134550.

6. Hooshmandi M, Hosseinmardi N, Janahmadi M, Khakpai F, Rohampour K, Doostmohammadi J. Antagonism of orexin type1 receptors (OX1Rs) attenuates naloxone-precipitated morphine withdrawal syndrome in rat dorsal hippocampus. Pharmacol Biochem Behav. 2017;158:39-48.

7. Clemans-Cope L, Holla N, Lee HC, Cong AS, Castro R, Chyi L, et al. Neonatal abstinence syndrome management in California birth hospitals: results of a statewide survey. J Perinatol. 2020; 40(3):463-72.

8. Xu NJ, Bao L, Fan HP, Bao GB, Pu L, Lu YJ, et al. Morphine withdrawal increases glutamate uptake and surface expression of glutamate transporter GLT1 at hippocampal synapses. J Neurosci. 2003;23(11):4775-84.
9. Zhang B, Wu L, Zhu Q, Dong Y, Sun L. Donepezil attenuates the development of morphine tolerance in rats with cancerinduced bone pain: The role of cortical N-methyl-D-aspartate receptors. Neurosci Lett. 2021;747(2021):135678.

10. Oge EN, Obese E, Biney RP, Adakudugu E, Agbenyeku M, Osei $\mathrm{SA}$, et al. A review of pharmacological effects of xylopic acid. Int J Basic Clin Pharmacol. 2020;9(5):6.

11. Woode E, Ameyaw EO, Boakye-Gyasi E, Abotsi WK. Analgesic effects of an ethanol extract of the fruits of Xylopia aethiopica (Dunal) A. Rich (Annonaceae) and the major constituent, xylopic acid in murine models. J Pharm Bioallied Sci. 2012;4(4):291.

12. Boampong J, Ameyaw E, Aboagye B, Asare K, Kyei S, Donfack $\mathrm{J}$, et al. The curative and prophylactic effects of xylopic acid on Plasmodium berghei infection in mice. J Parasitol Res. 2013; 2013:356107.

13. Steinmiller CL, Young AM. Pharmacological selectivity of CTAP in a warm water tail-withdrawal antinociception assay in rats. Psychopharmacology. 2008;195(4):497-507.

14. de Cordé A, Krzascik P, Wolinska R, Kleczkowska P, Filip M, Bujalska-Zadrozny M. Disulfiram attenuates morphine or methadone withdrawal syndrome in mice. Behav Pharmacol. 2018;29(5):393-9.

15. Varrassi G, Fusco M, Skaper SD, Battelli D, Zis P, Coaccioli S, et al. A pharmacological rationale to reduce the incidence of opioid induced tolerance and hyperalgesia: a review. Pain Ther. 2018;7(1):59-75

16. Gomes I, Gupta A, Filipovska J, Szeto HH, Pintar JE, Devi LA. A role for heterodimerization of $\mu$ and $\delta$ opiate receptors in enhancing morphine analgesia. Proc Natl Acad Sci. 2004;101 (14):5135-9.

17. Reiss D, Maurin H, Audouard E, Martínez-Navarro M, Xue Y, Herault Y, et al. Delta opioid receptor in Astrocytes Contributes to Neuropathic Cold Pain and Analgesic Tolerance in Female Mice. Front Cell Neurosci. 2021;15:745178.

18. Roman-Vendrell C, Yudowski GA. Real-time imaging of mu opioid receptors by total internal reflection fluorescence microscopy. Methods Mol Biol. 2015;1230:79-86.

19. Pradhan AA, Befort K, Nozaki C, Gavériaux-Ruff C, Kieffer BL. The delta opioid receptor: an evolving target for the treatment of brain disorders. Trends Pharmacol Sci. 2011;32(10): 581-90.

20. Yang PP, Yeh TK, Loh HH, Law PY, Wang Y, Tao PL. Deltaopioid receptor antagonist naltrindole reduces oxycodone addiction and constipation in mice. Eur J Pharmacol. 2019;852:265-73.

21. Mavrikaki M, Lintz T, Constantino N, Page S, Chartoff E. Chronic opioid exposure differentially modulates oxycodone self-administration in male and female rats. Addict Biol. 2021; 26(3):e12973.

22. Ward P, Moss HG, Brown TR, Kalivas P, Jenkins DD. Nacetylcysteine mitigates acute opioid withdrawal behaviors and CNS oxidative stress in neonatal rats. Pediatr Res. 2020;88(1): 77-84.

23. Moloudi MR, Moqbel H, Dastan D, Hasanzadeh K, Noori B, Izadpanah E. Effect of Hydro-alcoholic extract of Jasminum sambac on morphine withdrawal symptoms in rats. Sci J Kurdistan Univ Medical Sci. 2018;23(1):1-7.

24. Ebrahimi B, Esmaeili-Mahani S. The Effects of Hydroalcoholic Extract of Satureja khuzestanica on Naloxone-Induced Morphine Withdrawal Symptoms in Wistar Rats. Int J Basic Sci Med. 2020;5(1):16-21.

25. Jensen KP, DeVito EE, Yip S, Carroll KM, Sofuoglu M. The cholinergic system as a treatment target for opioid use disorder. CNS drugs. 2018;32(11):981-96.

26. Rada P, Pothos E, Mark GP, Hoebel BG. Microdialysis evidence that acetylcholine in the nucleus accumbens is involved in morphine withdrawal and its treatment with clonidine. Brain Res. 1991;561(2):354-56.

27. Liu X, Tian L, Cui R, Ruan H, Li X. Muscarinic receptors in the nucleus accumbens shell play different roles in context-induced 
or morphine-challenged expression of behavioral sensitization in rats. Eur J Pharmacol. 2018;819:51-7.

28. Foster SL, Galaj E, Karne SL, Ferré S, Weinshenker D. Celltype specific expression and behavioral impact of galanin and GalR1 in the locus coeruleus during opioid withdrawal. Addict Biol. 2021;25:e13037.

29. Fatemi I, Hadadianpour Z, Fatehi F, Shamsizadeh A, Hasanshahi $\mathrm{J}$, Abbasifard $\mathrm{M}$, et al. The role of locus coeruleus nucleus TRPV1 receptors in the development and expression of morphine dependence. Iran J Basic Med Sci. 2019;22(10):1186-91.

30. Fitzgerald PJ. Elevated norepinephrine may be a unifying etiological factor in the abuse of a broad range of substances: alcohol, nicotine, marijuana, heroin, cocaine, and caffeine. Subst
Abuse. 2013;7:171-83.

31. Bläsig J, Gramsch C, Laschka E, Herz A. The role of dopamine in withdrawal jumping in morphine dependent rats. Arzneimittelforschung. 1976;26(6):1104-06.

32. Bläsig J, Herz A, Reinhold K, Zieglgänsberger S. Development of physical dependence on morphine in respect to time and dosage and quantification of the precipitated withdrawal syndrome in rats. Psychopharmacologia. 1973;33(1):19-38.

33. Ameyaw E, Boampong J, Kukuia K, Amoateng P, Obese E, Osei-Sarpong C, et al. Effect of xylopic acid on paclitaxelinduced neuropathic pain in rats. J Medical Biomed Sci. 2013; 2(4):6-12. 